\title{
Body, Gender, and Sexualities Approaches in the Political-Pedagogical Project in a High School in Brazil
}

\author{
Alfrancio Dias ${ }^{1}$, Danilo Araujo de Oliveira ${ }^{1}$, Maria Helena Santana $\mathrm{Cruz}^{1} \&$ Simone Silveira Amorim ${ }^{2}$ \\ ${ }^{1}$ Federal Universtiy of Sergipe, Sergipe, Brazil \\ ${ }^{2}$ Tiradentes Universtiy, Sergipe, Brazil \\ Correspondence: Simone Silveira Amorim, Professor, Tiradentes University, Aracaju, SE, Brazil. Tel: \\ 55-79-3218-2100. E-mail: amorim_simone@hotmail.com
}

Received: November 23, $2016 \quad$ Accepted: January 10, $2017 \quad$ Online Published: May 29, 2017

doi:10.5539/ies.v10n6p1

URL: https://doi.org/10.5539/ies.v10n6p1

\begin{abstract}
The aim of this text is to analyse how the themes of body, gender and sexuality have been positioned in the Political-Pedagogical Project, a document that provides guidelines for all educational actions in a school, in a public state school located in the city of Aracaju (SE). We have adopted a post-critical and post-structuralist perspective, problematizing the processes of signification and how they influence the knowledge production and social relations, from the authors' readings: Carvalho (2010), Foucault (1988), Louro (2010), Scott (1995), Butler (2010). Methodologically, we have developed a quantitative approach, from the documental analysis in a cultural and social perspective. We have verified that body, gender and sexuality themes are introduced superficially, causing to be linked to lack of familiarity, as well as to the absence of initial and continued education formation of the school agents.
\end{abstract}

Keywords: body, gender, political-pedagogical project, sexualities

\section{Introduction}

The deconstruction of concepts, which hierarchize relationships and keep socially discriminated groups aside, has been gaining relevance in several knowledge fields, mainly in Human Sciences, from a questioning and inclusion perspective that the studies of body, gender and sexuality are included. In the educational field, it is not different as the academic context allows the discussion on the school taken as a multicultural place, undoing the pattern format of education that has historically neutralized the difference.

The schooling daily routine is dynamic, fluid and with unexpected experiences, which insert themselves in the pedagogical practices through the "hidden" or "informal" curriculum, permeating several questions in the classes and school daily routine. The programs of school subjects and the organizational management itself, many times, have not been appropriate to those matters, despising them, even if in adverse situations they show up.

The introduction of themes such as culture, multiculturalism, body, gender and sexual diversity, inequality, equity, difference, social class and ethnical relations in the school formal curriculum, in the school management and in the Political-Pedagogical Project (PPP) in teaching institutions should develop a more tolerant pedagogical practice regarding to differences. As those aspects define the teaching process, schooling practices, teachers' roles and the educational role institutions develop, it has been necessary to expand the view on those themes or grant greater visibility to the aims and strategies to be achieved during the school year, especially the ones that are proposed in the PPP.

Considering it, it has been valid to question how the body, gender and sexuality approaches have been inserted in the Political-Pedagogical Project of a high school public institution. What are those themes' role in the objectives, aims and methodologies of the Political-Pedagogical Project? Such questionings have worked as a "conducting wire" to the analysis of the inclusion and the importance of discussing on those themes in the school during the whole teaching process, in other words, its transversely aspects in the Political-Pedagogical Project, in the school curriculum and in the teachers' pedagogical practices.

In this text, we bring some initial results of the research developed in the Graduate Program in Education of the Federal University of Sergipe, entitled "The inclusion of the gender perspective in the initial and continued formation of basic education teachers", funded by CAPES (Coordination for Improvement of Higher Education 
Personnel). We have adopted, therefore, a post-critical and post-structuralism perspective, problematizing the signification processes and how they influence the knowledge production and the social relations from the reading of authors such as Carvalho (2010), Foucault (1988), Louro (2010), Scott (1995), and Butler (2010).

\section{Method}

The methodological premises are based on the qualitative approach, as it considers the necessity of a group of interpretative techniques to express the sense of social phenomena and the comprehension of the meanings of human actions and relations (Denzin, 2006). We have also considered that the qualitative research is closer to the perspectives of cultural studies analysis - gender images constitute as one of its analytical slope -, as well as gender studies have been inserted in the multiculturalism field, having as their main discussion agenda the ambiguity of identity/difference (Woodward, 2007; Hall, 2003). As a strategy of data collection, we have elected the documental analysis, aiming at producing knowledge related to the object, in a cultural and social perspective.

Initially, we have discussed on the approaches about body, gender and sexualities in the school and in the school curriculum. This research has been applied at a public school in Brazil called Colégio Estadual 17 de Março (March 17 State School). Later, we have presented the main results of the research with the analysis of the Political-Pedagogical Project, which is a document that must guide all the actions related to education that take place in or out the school's facilities. Its organization has to be the result of a collective project with the participation of all who are part of the school's community.

\section{The Approaches about Body, Gender and Sexualities in the School}

The characteristics attributed to men and women must be questioned and denaturalized as they are part of a historical process of construction. Gender studies arise as an analytical and political tool, which allows comprehending "the fundamentally social character of distinctions based on gender" (Scott, 1995, p. 72). We intend to problematize the ways through which the man/woman binary aspect, lined by the biological framework, has been built and scattered in social relations. The ways of representation of senses and meanings that we attribute to male and female roles and places have brought out the masculinities and femininities demarcated by heteronormativity. Ways of dressing, behaving, acting and thinking have been determined to men and women in a different way, as if gender would already grant power to men and submission to women. It is exactly some of these aspects and many others that gender studies have been questioning. Therefore,

[...] that forces those who employ them to take into consideration the different societies and the different historical moments they have been dealing with. It moves away (or intends to do so) from the essentialist propositions about genders; the optics have been directed to a process, to a construction, and not to something that exists a priori. Concept starts to demand that one's thinks in a plural way, highlighting that projects and representations about both men and women are diverse. It has been observed that gender conceptions differ not only among societies or historical moments, but in the inner side of a certain society, when considering the miscellany of groups (ethnic, religious, racial, social class) that constitute it (Louro, 2010, p. 23).

Such perspective gives rise to the necessity of noticing the cultural construction of gender demystifying the male power that changed the female into the second gender, placing the woman in a condition of being submissive, restricting her to the private space. To Louro (2010), we have to abandon the gender essentialist speeches, primarily linked to the dichotomist aspect sex/gender, in order to think of it from the idea of culture. The meanings we have about men and women should be modified by the social relations demarcated by time and space. This way, as we talk about gender we have to take into consideration the fluidity of representations and meanings that men and women attribute to their bodies, their desires and their sexuality. In this historically uneven scenery, gender studies and their intersections with studies about body, sexualities, religion and ethnic-racial and generational studies have contributed to the reduction of power asymmetry and to the increase of equity.

Gender is a category architected from cultural, social and psychological constructions and not biologically defined, it is a category of analysis. Studying gender categories means to think of how they have been structured, to examine it means to establish an either social or symbolic relation. While analyzing gender inequalities, we cannot abstract class, ethnicity and race inequalities which make even more dramatic the individuals' experiences and, more specifically, the women's ones (Cruz, 2014, p. 10).

These discussions imply to detect that gender studies not only include female submission, they allow to comprehend all the experiences individuals are subjected to and to question inequalities in the relations, no 
matter if they are concrete or symbolic. They still allow comprehending historical aspects, which are imbricated in such relation, undoing a view that neutralizes differences, by silencing those speeches that are aside from what has been instituted as universal patterns. During the process of construction of gender, relations have been established through a pole of power in which the male pattern is a "universal pattern" (Bourdieu, 1999, p. 17), placing men in a privileged place on the social relations during the exercise of power.

The exercise of power is not only a relation between individual or collective "couples"; it is a way of action over others. Which means, since now, that there is nothing called Power, the power that would exist universally, in a massive or diffuse way, either concentrated or distributed. There is only the power they exercise over "each other". The power only exists in an act, however, since it has been registered in a field of dispersed possibilities, leaning on permanent structures. That also means that power is not a kind of acceptance. Power itself is not renunciation to a freedom. Transfer of detained rights in order to someone represents you? (Which does not prevent acceptance to be a condition to the existence or maintenance of a relation of power; the relation of power might be the effect of a permanent or previous acceptance, but not by the nature the manifestation of a consensus (Foulcault, 1988, p. 14).

Power relations permeate the whole normative scheme of a speech which aims at hierarchizing, subordinating and excluding. They have been gaining much more room through the instruments that are represented in politics, religion, sciences and several institutions, controlling populations in a wider and wider way, disseminating a relation of proximity to the instituted standard. This way, aiming at deconstructing such standards, cultural studies contribute with new ways of thinking of the subject, understanding how the production of culture and the dominant systems give a meaning to the subjective experiences and everyday life.

Being the school a socialization place, an instrument of power, it has been a tool to the maintenance of ideologies. Bourdieu (1999) affirms that the curriculum is based on the dominant culture. It is necessary to comprehend how dominant ideologies have been inserted in the curriculum along history, how people used to notice each other and how they used to build their fixed identities of subordination and they did not use to question their room, as "[...] it is through the link among knowledge, identity and power that themes such as race and ethnic group get their room in the curricular territory" (Silva, 1999, p. 107). In this sense, subjects are, therefore, the result of a cultural and social process that school produces and reproduces continuously. The post-critical studies have questioned the ideological power of school, contesting the idea of fixed identities, showing how the individuals in late modernity present their fluid and defragmented identities. The identity fully unified, complete, safe and coherent is fantasy. Instead, as signification and cultural representation systems multiply we have been confronted by a disconcerting and changing multiplicity of possible identities, with each one of those we could identify - at least temporarily (Hall, 2003, p. 13).

The inclusion of these themes in school through multiculturalism allows the deconstruction of the trend to homogenization, to standards, emphasizing the recognition of difference, in a process of permanent confrontation and not hiding the other. That is why it is important to recognize multiple identities, which are inserted in the school, allowing the dialogue and empathy with the other who collaborates and interferes in such exchange of knowledge and in our identities constructions. In this regard, the ongoing speech allows demystifying the solid notion of a unique way of masculinity and femininity, which perpetuates a standard of behavior according to the gender, instituted by society. Therefore, cultural studies on the gender perspective carry the function to make us notice "[...] the cultural production processes also from the (current and historical) participation of groups that, socially marginalized, have not been recognized by their contributions to modern culture" (Adelman, 2006, p. 1). Recently, groups have been presenting in an acting and contesting way in speeches.

The constructions mentioned so far reflect in a meaningful way on the subject's bodies, because it is on them that representations find materiality. Normative descriptions naturalized and legitimated by Biology demarcate space on the individuals through their bodies, gaining represent ability and sense. When these standards flee from the established rule, they are immediately questioned. In this sense, "the individual builds the evidence of their behaviour as a man or a woman, not always are aware of that, as they have acquired the principle of such behaviours along their childhood, through socialization, and their confirmation depends on the ordinary game of existence (Le Breton, 2014, p. 19).

We can state as an example of "female nature" the woman's body, which is seen as fragile and holder of sensibility that, for instance, categorize and base maternity, placing the woman aside. Thus, it could be stated: "[...] male's look and speech sexualize the woman's body. Maternal instinct and love become mechanisms of controlling female sexuality" (Araujo, 2009, p. 113). The notions of man and woman that we individualize are 
not essences, they are transmitted, they are constructions of intelligibility of the body through the social aspect as they are polarities that have been instituted. It has been noticed, through the historical context, that this is nothing about a natural matter, but something socially instituted, in which to men, the power of reason has been designated and, to women, the reproduction instinct, established through their body. Having said that, it has been evident:

The ways of being and having been in the world that became hegemonic concern to the ways bodies, genders and sexualities have been thought of and produced, reduced to fragmented, imprisoned and binary dimensions. Generalized and naturalized, heterosexuality, inserted in the body, has become reference everywhere and to everybody, as Guacira Louro has stated since 1999. This way of sexuality has invaded school texts and pedagogical procedures which aimed at educating boys and girls, and still remain in them in this very beginning of the XXI century (Silva, 2014, p. 67).

Such discussion leads us to think about the body as a social-cultural construction, by considering masculinities and femininities and other several ways related to biological bodies, whereas the body cannot be thought decontextualized from gender.

These days, as it has been formerly, Biology is a political chapter. Sex, as well as body, is a crystallization of social meanings, including in its description that it would not be able to escape from categories of sense and values. The body does not determine identity anymore, it is at its service (Le Breton, 2014, p. 32).

Through this context it has been arisen the challenge of articulating the ordinary with the plural, equality with difference, promoting discussions on how prejudice is produced, which might be the school's expression towards the diversity of identities, sexual and gender differences of the individuals involved in school relations, emphasizing also their intersections with matters of social class and race.

Several social problems occur from sexism, heterosexism and gender inequity, associated to other inequalities, and they reflect on school: discrimination and violence, teenage pregnancy, women's, domestic and remunerated work exploration/devaluation, including the teaching work, paternity omission and the deriving mothers' overload. And the school take part in that either direct or indirectly, in action or omission, in the construction of those problems and inequalities, giving inequal treatment to students and legitimating prejudicious world's and subject's view (Carvalho, 2010, p. 79).

The school daily routine influences, it is an opinion leader and it is discursive. Therefore, there is the need to insert in the teaching and learning processes practices that project a school curriculum that is according to the contemporary world, which is more and more heterogeneous. Having this in mind,

The schooling institution is a privileged site of socialization, where it is given special attention to the way subjects, in social relations, crossed by different speeches, symbols, representations and practices, constructing their identifications, (re)constructing their social places, their dispositions, their ways of being and having been in the world (Dias, 2014, pp. 64-65).

It has been said, therefore, that educative processes are related to socialization, and it is vital to the comprehension of gender analysis in the schooling institution, aiming at contributing to non-sexist behavior and practices as well as the acceptance of diversity and tolerance towards the other. Considering it, the school will be contributing to the questioning of the established rule, breaking a patriarchal history, which has consolidated for a long time an androcentric and racist school curriculum. Not opting for such alternative means that the school keeps the dominant order and neutralizes subordinate behaviors.

That does not mean that we have adopted a naive, utopian or reductionist attitude concerning educational institutions, as we comprehend that those do not hold the power of eliminating sexist practices, however, they might assume a critical, attentive and problematized attitude concerning its practices and components (Oliveira, Ramos \& Silva, 2011, p. 102).

The inclusion of themes in schools has not been restricting the power of modifying the social order historically established, but as a proper place to problematize those matters, give them visibility and question attitudes that legitimate binary standards towards a sexist and prejudiced logic. Besides being a practice that must be present in everyday practice, those themes must be in the Political-Pedagogical Project, in the School Curriculum, in the Course Plans, as a register of practice, also as a goal to be followed.

\section{Body, Gender and Sexuality in the School Curriculum}

It is possible to reflect on how the body, gender and sexuality studies have been so imbricated and present in the school context, even in a hidden way, and not having gained the relevance they should have. The school daily 
routine has been marked by instruments that mold and legitimate the pedagogical practice, which control and segregate subjects, but at the same time, might be questioning and liberating.

By analyzing the Political-Pedagogical Project as an integrator element between theory and practice, subject and object, knowledge and reality, its social relevance and pertinence to the schooling institution is much important to dialogue with the assumptions of a changing and critical education, as there should be the inclusion of gender perspective in its methodology.

The Political-Pedagogical Project has arisen in a historical context of transition, after two decades of military dictatorship in Brazil (1964-1985), which had controlled all instances of public institutions, including the school. By the time it was over, the democratization movement in the country brought a great challenge that was to propose to break down the barriers delimitated by the Interventionist State from the previous political regime. One of those barriers was the democratic management of public education.

Only later, in 1996, with the National Education Guidelines and Framework Law - Law 9.394 of December 20, 1996 (Brazil, 1996), all teaching institutions have been given the task to elaborate and put into practice their own pedagogical proposals. For that that matter, it should be guaranteed that every schooling community participated in the process, giving "voice" to all sectors that compose the school so that they would create an active and practical tool.

Democratic management must be impregnated of a certain atmosphere that everyone breathe in the school's facilities, in circulating information, in sharing the work, in establishing the school calendar, in distributing the classes, in the process of elaboration or creation of new courses or new school subjects, in creating working groups, in training human resources etc. Democratic management means, therefore, attitude and method. Democratic management is necessary, but not sufficient. We need democratic methods that support the effective exercise of democracy. It is also a learning process, it demands time, attention and work (Gadotti \& Romão, 1997, p. 36).

This new pattern created to improve the school quality brought to it those who have been previously excluded from the public teaching system. Diversity started to compose its premises and soon occurred the necessity of adjusting it to reality. Aiming at referencing schools, the federal government has instituted the National Curricular Parameters - PCNs (Brazil, 1997), bringing, besides the content of compulsory subjects, the transversal themes that permeate the school daily routine and that are responsible for the construction of a critical and active citizen in society.

Besides giving some thoughts about the historical process and questioning the constructions previously mentioned, the value of the difference and the respect to the several ways of manifestation of identities are perspectives adopted by the gender studies. Being the school considered as a primary former of critical individuals who can be able to respect the difference, it becomes an important place to talk about and spread the concept of gender.

Even with the changes the Federal Constitution of 1988 (Brazil, 1988) offered in defense of rights - according to the subsection $V$ of the 3rd article, which says: "[...] without prejudice of origin, race, sex, color, age any other way of discrimination" (Brazil, 1988) - the notion of gender is still poorly defined in the educational field. Sometime later, in 2000, Brazil signed the "Jomtien Declaration", a document elaborated in the World Conference on Education for All (Unesco, 1990), from which, among the eight goals established to the improvement of life conditions by the United Nations, it was highlighted the need for the equality promotion among genders and women's empowerment.

That has been a continuous challenge to be faced by the schooling institution that proposes to take responsibility on the construction of a location that supports diversity and also holds the need of prioritizing equality of conditions, respect among all individuals, considering the main documents that guide and legitimate the teaching and the human rights protection. As highlighted by Viana and Unbehaum "[...] the elaboration of the PCNs, between 1995 and 1997, has aimed at guiding the basic and secondary education all over the national territory, representing an important step in the inclusion of gender perspective in education" (Viana \& Unbehaum, 2006, p. 416).

Thinking about significant aspects related to gender in the Political-Pedagogical Project is a way to overcome the silence imposed for so much time over school. The National Curricular Parameters (Brazil, 1997) is a legitimate support that the teachers have to deal with that matter in their practice. Therefore, bringing the themes of sexuality, body and gender to a document that aims at guiding their practice is a lot important to facilitate even more their inclusion in the pedagogical context in the school. 


\section{Results: A Look at the Inner Side of School}

This research has been applied at a public school in Brazil called Colégio Estadual 17 de Março (March 17 State School). The starting point to this research was to present the proposal to the directory board of the school, by describing how the research would be carried out and how it would contribute to the school. The directory board seemed accessible and indicated the legal paths that would allow us to proceed with it, so a request letter to access the document-the PPP-with the research description was written and handed in. This way, we have presented the main questions that guided the research conduction: Does the methodology described in the Political-Pedagogical Project contemplate the studies of body, gender and sexuality? How are these themes addressed in the document? How does the school notice and understand diversity?

The Political-Pedagogical Project refers to the years 2014 to 2016 and had been elaborated after changes made by the directory board, in January 2014. After that it was approved by the schooling community, keeping the criteria of participation of all. Highlighted in the inside cover a statement by Paulo Freire was registered:

Planning the practice means having a clear idea of the goals we want to achieve with it. It means knowing the conditions under which we will act, the tools and the means that we have. Planning the practice also means to know who we can count on to execute it (Freire, apud Sergipe, Colégio Estadual 17 de Março, 2014, p. 2).

The illustrative sentence in the Project reveals the core of the schooling document as a proposal of action. Right after the identification of the school, of the directory board and of the teaching staff during the presentation, the institution revealed their conception of a PPP:

The Political-Pedagogical Project represents the school's administrative, financial and pedagogical organization which guides its pedagogical activities as to give a course towards the resolution of its educational, infrastructure, human and material resources problems, pursuing an improvement in the teaching-learning process (Sergipe, Colégio Estadual 17 de Março, 2014, p. 7).

It was stated that the PPP was supposed to guide the school taking into consideration aspects that involve physical structure, providing quality education, ludic and technological resources, materials that assist the teacher in the classroom, financial sources to maintain its functioning. It is important to mention that, besides guiding the organizational, administrative and financial aspects; it is also pedagogical, guiding the teaching and learning process. That is why it is important to include in its perspective conditions that consider in the proposed practices actions which must face a speech that hierarchize and marginalize the individuals involved in the process, recognizing the school as a place of democratic experiences where everyone has a voice, undoing the stereotypes which permeate the pedagogical practice.

In the topic Theoretical Aspectss, the principles on which the pedagogical work would be based, were described, from which we can highlight: "Encouraging students to think and freely express themselves, preserving the defenses of public interest" (Sergipe. Colégio Estadual 17 de Março, 2014, p. 8). Even bringing the subjectivity of freedom to the students' expression, it has been noticed that there is a limit when, after the comma, it brings the word "preserving"; it is, then, convenient to question: What it this public interest? What about the cultural standard? Are these the speeches that society brings silence?

It is known that speeches constitute the individuals, producing "[...] places from where individuals can place themselves [...]" (Woodward, 2000, p17) and the ways they should behave according to the standards instituted in a biological way. The school reflects and reproduces that in its speech, normalizing the bodies from this sexist determination. According to Reis and Paraíso, "[...] in this production of the subject's positions through the speeches, some have been constituted as normal and intelligible and others have not [...] from culturally established standards" (Reis \& Paraíso, 2014, pp. 239-240).

It is important to mention how the school defines its general objective: "[...] to provide changes in the School in order to no longer be bureaucrat, and having as its goal their students' learning, developing in them their critical, participative and creative spirit, making them active citizens in their environment" (Sergipe. Colégio Estadual 17 de Março, 2014, p. 10). Such conception reflects that the institution notices the student as active and not only as a simple content receiver. It perception is positive, as students themselves have the possibility to question transgressive practices that school might exercise, before a cultural construction to which it is submitted as an ideological body of the state in the reproduction of ideas that may not make plurality possible. The school reinforces its intention through goals and presents it priority: "[...] to promote changes through lectures, meetings, discussions and research" (Sergipe. Colégio Estadual 17 de Março, 2014, p. 10). This idea is reinforced when it can be read in the document that, 
In the present reality, where people are used to living in misery and social exclusion, it is the school's role to form opinion leaders, citizens of the third millennium to seek ways of building a society for all, where exclusion and inequality are replaced by justice and equal opportunities (Sergipe. Colégio Estadual 17 de Março, 2014, p 7).

Even if the school shows it is open in attitude, in general, in some institutions there is still an exclusion process that although it can be considered a socialization place, actions are predetermined by the schooling routine, in which male and female characteristics are highlighted.

Although it has been realized the socialization work developed in the schooling institutions routine, this has been constituted as a process of 'indoctrination' of place/time thought to attend male and female characteristics of the individuals who perform the schooling everyday routine. Ways of body behaviors, disciplinary contents, curricula and languages in the school practices allow a certain control in the schooling process, mentioned as natural ones (Dias, 2014, p. 65).

Gender studies have also put pressure on the school to assume it position as a collective place, its characteristic of being a public site of impingement of social problems, of sheltering vulnerable and marginalized individuals, having the opportunity to promote respect to diversity.

The highlight made by the school in its PPP mentioned before might indicate an advance, even in a superficial way, favoring the deepening of a confrontation policy, by considering gender, sexual identities and minorities approaches towards the "opportunities of equality" in a way the institution sees itself as an appropriate site to this action happens. For that reason, it is such a present and necessary discussion in the schooling context, considering the several ways the school acts to the formation of individuals, as a creator of knowledge and soon as a place of meaningful experiences.

The socioeconomic context the school is placed in, despite being characterized in the document as "relatively good", has revealed that the attendance is directed to needy students who come from neighbor communities. It is a challenge to the institution, therefore, to reinsert those individuals in the society, modifying their reality, understanding education as modifier of an excluding reality in which groups are segmented according to their social classes. The main limitations stated are students' family experiences that according to the document live only on one minimum wage even with a big family. Not to mention that most kids are supported and taken care by their grandparents. Parents, besides not being literate, work the whole day, making it difficult to follow their children's development in school. In this sense, the school tries to mediate conflicts aiming at changing the family absence status.

The reality in which the school has been inserted allows much more, in terms of what can be made, in its practice, as well as in the document that guides it, which highlights actions as gender equality and the inclusion of the diversity perspective are contemplated. All aspects involved in such reality comprehend how the hierarchization of social relations happens in our society: through power relations, promoting discussions based on experiences, rousing discussions, promoting education in human rights and the valuation of diversity.

Concerning the Strategic View, the school has highlighted participation, equality, transparence, integration in its mission and future view. Herein we highlighted the notion of equality stating that "[...] we are all equal, there is no distinction of this or that, no matter of education level or job position one holds" (Sergipe. Colégio Estadual 17 de Março, 2014, p. 16). It is possible to recognize a reductionist view of equality, concerning the subjectivity that the pedagogical work is in the promotion of equality and as the public school being a place where the minorities pass by their everyday lives and who are weakened by their conditions. The School Atmosphere also deserves relevance, as it is stated not to be found in the school "[...] discrimination of color, race, religion, social class etc., being all treated with equality" (Sergipe. Colégio Estadual 17 de Março, 2014, p. 16).

From the moment a school allows such discussions, those representations are problematized, as in the school's document this concern is already inserted, that means the school may have started to work on those matters. Besides, it has been noticed that gender and sexual identities discriminations have not been contemplated at the moment the school states that in the schooling daily routine no discrimination cases has been identified. That might reveal that school agents are not familiar with the themes object of this article.

In another piece of the document, entitled "Effectiveness in the Teaching-Learning Process", it has been stated that the curriculum is organized and articulated with the National Curricular Parameters (1997), it has not been mentioned at any time the transversal themes, and the body, gender and sexualities discussions are absent from the document just mentioned. That might reveal the lack of qualification of those involved in the construction of the Political-Pedagogical Project, before a discriminator education that has not contemplated the gender, body 
and sexuality speech, what may become object of study in a future research.

\section{Discussion}

From the analysis of the document-PPP of Colégio Estadual 17 de Março-it has been revealed that gender, body and sexuality constructions are superficial in such an important document to the school, which shows that there is much to advance on the guidance of practices that give importance to a formation to diversity.

It is necessary that the school curriculum highlight and grant visibility to gender equity, to those groups socially marginalized and to women, through the insertion of such aspects in the objectives that conduct and guide the pedagogical actions taken to form citizens who are aware of the ideas related to an education in sexuality and gender. Some governmental actions have been calling attention of school staff to this necessity, aiming at stimulating the implementation of those documents, training the professionals that will provide opportunities to discuss sexuality and gender in the school's facilities. Even though it is a great challenge to introduce those themes in the school, it is necessary to review the need of dissemination of information and education, as a subjective right of the human being, so that an attitude of respect to diversity might be developed.

The school should not coadunate with the perpetuation of constructions that standardize hierarchies based on stereotyped conceptions on the male and female binarism, but should enable an open and empathetic approach, questioning universalism in an intercultural optic. And that must be in the documents which legitimates its practice: the PPP.

This research is limited, at first, to a documental analysis, but it has been noticed that the Political-Pedagogical Project takes a big step by bringing the perspective of difference, to accept the others the way they are. However, it is also necessary to bear in mind that inside the school, relations are relations of power, consequently relations between teachers and students e the other relations, which involve the school, tend to reproduce situations and experiences of prejudice, discriminations and hierarchies that come from the relations out of the schooling environment. It means that the experiences of school, family and professional agents tend to influence the students' representations.

\section{References}

Adelman, M. (2006). Estudos culturais e estudos de gênero: Entendendo os olhares. Cadernos da Escola de Comunicação, $\quad 4(1), \quad 1-19 . \quad$ Retrieved $\quad$ from http://revistas.unibrasil.com.br/cadernoscomunicacao/index.php/comunicacao/article/view/40/40

Araujo, J. R. (2009). Relações de gênero na educação infantil: Questionamentos acerca da reduzida presença de homens na docência. In A. B. M. Teixeira, \& A. Dumont (Eds), Discutindo relações de gênero na escola: reflexões e propostas para a ação docente. (pp. 67-86). Araraquara (SP): Junqueira \& Marin.

Bourdieu, P. (1999). A dominação masculina. Rio de Janeiro: Bertrand Brasil.

Brazil. (1996). National Education Guidelines and Framework Law n. 9.394, 20th of December, 1996. It stablishes the guidelines and the support for the education nationwide. Diário Oficial da União Brasileira, DF, 23 dez., p. 27894.

Brazil. (1997). Ministry of Education and Sports. Secretary of Basic Education. National Curricular Parameters: Basic teaching. Brasília, DF: MEC/SEF.

Brazil. (2001). Constitution (1988). Federal Constitution of Brazil. Brasília, DF: Oficial Press.

BUTLER, J. (2010). Problemas de Gênero: Feminismo e subversão da identidade (3rd ed.). Rio de Janeiro: Civilização Brasileira.

Carvalho, M. E. P. (2010). Gênero é um conceito complexo e de difícil sensocomunização. Considerações a partir de uma experiência de formação docente. R. Est. Pesq. Educ. Juiz de Fora, 12(2), 75-87. Retrieved from https://instrumento.ufff.emnuvens.com.br/revistainstrumento/article/viewFile/937/800

Cruz, M. H. S. (2014). Gênero e diversidade na escola. (Aula Inaugural: - CURSO DE APERFEIÇOAMENTO EM GÊNERO E DIVERSIDADE NA ESCOLA). CESAD/NUPAT/UFS.

Denzin, N. K. (2006). O planejamento da pesquisa qualitativa: Teorias e abordagens. Porto Alegre: Artmed.

Dias, A. F. (2014). Representações sociais de Gênero no trabalho docente: Sentidos e significados atribuídos ao trabalho e a qualificação. Vitória da Conquista (BA): EDUESB.

Feire, P. (1996). Pedagogia da autonomia: saberes necessários à prática. São Paulo: Paz e Terra.

Foucault, M. (1988). El sujeto y el poder. Revista Mexicana de Sociologia, año L, n.3, jul.-sep. 
https://doi.org/10.2307/3540551

Gadotti, M., \& Romão, J. (1997). Autonomia da escola: princípios e propostas. São Paulo: Cortez, 1997.

Hall, S. (1999). A identidade cultural na pós-modernidade. Rio de Janeiro: DP\&A.

Hall, S. (2003). Da diáspora: Identidades e mediações culturais. Belo Horizonte: UFMG.

Le Breton, D. (2014). Corpo, gênero, identidade. In A. Ferrari (Ed.), Corpo, gênero e sexualidade. Lavras (MG): UFLA.

Louro, G. L. (2010). Gênero, sexualidade e educação: Uma perspectiva pós-estruturalista. Petrópolis: Vozes.

Oliveira, K., Ramos, E. S. da S., \& Silva, S. (2011). Relações de gênero e educação. Revista Sociais e Humanas. Centro de Ciências Sociais e Humanas - Universidade Federal de Santa Maria, Rio Grande do Sul, Brasil. 24(2). Retrieved from https://periodicos.ufsm.br/sociaisehumanas/article/view/2884/2857

Reis, C. d'Á., \& Paraíso, M. A. (2014). Normas de gênero em um currículo escolar: a produção dicotômica de corpos e posições de sujeito meninos-alunos. Estudos Feministas, 22(1). https://doi.org/10.1590/S0104-026X2014000100013

Scott, J. (1995). Gênero: uma categoria útil de análise histórica. Educação e Realidade, 20(2). Retrieved from http://compromissoeatitude.org.br/wp-content/uploads/2012/08/JoanScott_Genero_umacategoriautil.pdf

Sergipe. Colégio Estadual "17 de Março". (2014). Projeto Político Pedagógico. Aracaju.

Silva, E. P. Q. (2014). Entremeando corpos, sexualidades, gêneros e educação escolar. A. Ferrari (Ed.), Corpo, gênero e sexualidade. Lavras (MG): UFLA.

Silva, T. T. (2014). Documentos de identidade: uma introdução às teorias do currículo. Belo Horizonte: Autêntica.

UNESCO. (1990). World Declaration on Education for All: framework for action basic learning needs. Retrieved from http://unesdoc.unesco.org/images/0012/001275/127583e.pdf

Viana, C., \& Unbehaum, S. (2006). Gênero na educação básica: quem se importa? Uma análise de documentos de políticas públicas no Brasil. Educação e Sociedade. Campinas, 27(95). https://doi.org/10.1590/S0101-73302006000200005

Woodward, K. (2007). Identidade e diferença: uma introdução teórica e conceitual. Silva, T. T. Identidade e diferença: A perspectiva dos estudos culturais.7. ed. Petrópolis (RJ): Vozes.

\section{Copyrights}

Copyright for this article is retained by the author(s), with first publication rights granted to the journal.

This is an open-access article distributed under the terms and conditions of the Creative Commons Attribution license (http://creativecommons.org/licenses/by/4.0/). 